\title{
Tropical inselbergs: habitat types, adaptive strategies and diversity patterns
}

\author{
STEFAN POREMBSKI ${ }^{1}$
}

(received: December 7, 2004, accepted: September 26, 2007)

\begin{abstract}
Tropical inselbergs: habitat types, adaptive strategies and diversity patterns). Inselbergs are isolated rock outcrops that rise abruptly above the surrounding plains. Granitic and gneissic inselbergs are geologically and geomorphologically old and occur throughout a broad spectrum of climatic zones. They form microclimatically and edaphically dry growth sites that support a highly specialized vegetation. Based on physiognomic criteria a number of habitat types can be distinguished that are widespread on inselbergs (e.g. ephemeral flush vegetation, monocotyledonous mats, rock pools). Three hot spots of global inselberg plant diversity can be identified which are both rich in species and endemics: a) southeastern Brazil, b) Madagascar and c) southwestern Australia.
\end{abstract}

Key words - adaptive traits, conservation, endemics, rock outcrops, species richness

RESUMO - (Inselbergs tropicais: tipos de hábitats, estratégias adaptativas e padrões de diversidade). "Inselbergs" são afloramentos rochosos isolados que emergem abruptamente acima das planícies que os cercam. Inselbergs graníticos e gnássicos são geologicamente e geomorfologicamente antigos e ocorrem ao longo de um amplo espectro de zonas climáticas. Eles formam sítios de crescimento que são microclimaticamente e edaficamente secos, e sustentam uma vegetação altamente especializada. Vários tipos de hábitats podem ser distinguidos, com base em critérios fisionômicos, que são comuns a vários inselbergs (e.g., vegetação de floração efêmera, "tapetes" de monocotiledôneas, "panelas" rochosas). Três regiões importantes do mundo com diversidade de vegetais típicos de inselbergs, podem ser apontados, que são ricos tanto em espécies quanto em endemismos; são elas: a) o sudeste do Brasil, b) Madagascar e c) o sudoeste da Austrália.

Palavras-chave - afloramentos rochosos, características adaptativas, conservação, endemismos, riqueza de espécies

\section{Introduction}

Many oceanic islands are well known for possessing a flora and fauna which are characterized by considerable numbers of morphologically and ecologically unusual taxa that are frequently endemic. The uniqueness of oceanic islands with respect to their plant and animal inventories is a consequence of their geographic isolation and has attracted the interest of numerous researchers. Their role in advancing new ideas and concepts is widely accepted (e.g., Charles Darwin's view on evolutionary processes or the theory of island biogeography proposed by Robert H. MacArthur and Edward O. Wilson).

Spatial and ecological isolation as a barrier against dispersal and migration of potential immigrants is not confined to oceanic islands. Numerous mainland ecosystems are likewise isolated due to their possession of particular ecological attributes. Among terrestrial habitat-islands individual mountain peaks, caves, and kettle holes form prominent examples. In contrast to oceanic islands, however, terrestrial habitat-islands have been somewhat neglected

1. Universität Rostock, Institut für Biodiversitätsforschung, Allgemeine und Spezielle Botanik, Wismarsche Str. 8, D-18051 Rostock, Germany, stefan.porembski@uni-rostock.de when testing hypotheses about evolutionary processes and species diversity. The reasons for this disregard of terrestrial habitat-islands are manifold. Oceanic islands are frequently of considerable antiquity (i.e. millions of years) and they tend to occur in spatial isolation over large distances (i.e. thousands of $\mathrm{km}$ ). In comparison terrestrial habitat-islands possess two obvious advantages when used as model systems: few are of comparable age and the degree of their spatial isolation is usually much less. A potential surrogate for geographic distance is ecological distinctiveness. Amongst terrestrial habitat islands, inselbergs form an exception in being old (i.e. millions of years) and in having unique ecological characteristics. The latter enhances the effects of isolation and may thus compensate for the usually lesser degree of geographic isolation. Granitic and gneissic inselbergs are frequently dome-shaped and rise more or less abruptly above the surrounding landscape (figure 1). They form geologically and geomorphologically old landscape features that are widespread on the crystalline continental shields. Inselbergs occur throughout all major climatic and vegetational zones but are particularly abundant in certain tropical regions. Despite their widespread and sometimes dominant occurrence over a vast spectrum of landscapes the history of their biological exploration is relatively short. 


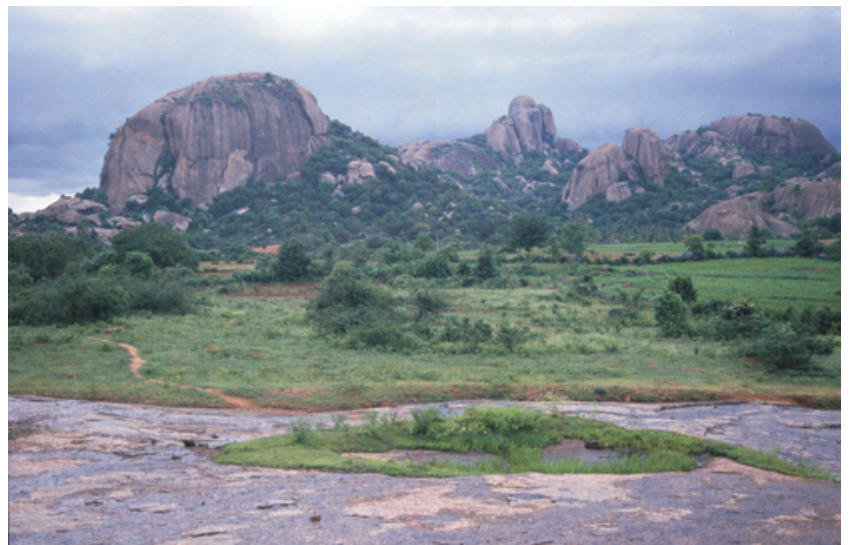

Figure 1. Granitic inselberg in southern India (near Bangalore, Karnataka).

Early descriptive accounts of the vegetation of inselbergs date back to the $19^{\text {th }}$ century with a number of naturalists (e.g., Carl Friedrich von Martius and Alexander von Humboldt). From a biological point of view inselbergs in the tropics have largely been neglected until today. This has changed only in the last decade as studies in tropical Africa and South America have improved our understanding of their flora and vegetation. A summary of these recent developments can be found in Porembski \& Barthlott (2000). There are nevertheless, still large gaps in our knowledge of basic floristic data of inselberg vegetation and ecology in many regions of the world.

\section{Environmental conditions on inselbergs}

The geomorphological and geological characteristics of granitic and gneissic inselbergs have been dealt with in detail by Thomas (1994) and Bremer \& Sander (2000). With regard to absolute height and surface area inselbergs cover a vast spectrum. Absolute height ranges from a few meters ("shield inselbergs") to several hundred meters and surface area reaches from small outcrops covering several square meters to large domes extending over square kilometres. The degree of geographic isolation of inselbergs is varied. They can occur as hills isolated over hundreds of kilometres or they can form dense clusters with individual outcrops occurring at distances of only a few kilometres.

Various authors (e.g., Phillips 1982, Szarzynski 2000) have recorded microclimatological conditions on both temperate and tropical inselbergs. On open rocky slopes air temperature and insolation regularly reach values that are considerably higher than average values in surrounding vegetation types. For example, air temperature on inselbergs in West Africa frequently exceeds $40{ }^{\circ} \mathrm{C}$ and peaks over $60{ }^{\circ} \mathrm{C}$ when measured directly on the rock. Moreover, inselbergs are characterized by low relative air humidity which frequently drops below $20 \%$ during the day. Consequently, inselbergs form microclimatic "deserts" (Phillips 1982). In addition, the widespread lack of soil contributes further to their environmental harshness. Soil occurrence on inselbergs is locally very restricted. Bremer \& Sander (2000) provided data on substrate properties and demonstrated that lithosols with various humus contents are widespread. Published data on nutrient availability on inselbergs indicate that for instance phosphorus and nitrogen are severely limited (Dörrstock et al. 1996).

Due to the absence of large accumulations of soil little rainwater is stored but is instead rapidly lost as run-off. The loss of water due to run-off is considerably enhanced by the frequent steep slope inclinations. The latter fact adds further to the severity of the environmental conditions in making the long-term establishment of vegetation difficult due to gravitational stress. Frequently the dislodgement of individual plants and whole mats can be observed which are particularly susceptible of becoming detached from their rocky substrate during rainstorms when saturated with water.

Despite the general lack of moisture a number of locally restricted habitat types occur which are characterized by seasonally wet conditions. Most prominent are seasonally water-filled depressions ("rock pools") which may carry water for several consecutive weeks or months. Wet conditions are also present where water seeps continuously over longer periods. This is the case at the feet of steep rocky slopes where an ephemeral vegetation develops. However, unpredictable periods of drought may cause the drying up of wet sites even during the rainy season thus triggering local extinction events on inselbergs.

\section{Plant communities and habitat types on inselbergs}

As a consequence of the harsh environmental conditions on inselbergs their vegetation is clearly demarcated from their surroundings. The extent of the expression of the island-like character of inselbergs (i.e., ecological isolation) depends on the surrounding vegetation types with tropical rainforest emphasizing particularly profoundly the floristic differentiation between rock outcrops and their surrounding matrix.

Based on phytosociological analyses and physiognomic criteria a limited set of typical plant communities and habitat types can be distinguished (for details see also 
Porembski et al. 2000) which occur on inselbergs over a broad geographical scale. The most important ones are described concisely in the following.

Cryptogamic crusts - Vast areas of exposed rocks on inselbergs are covered by cyanobacterial lichens (frequently Peltula spp.) and cyanobacteria (often Stigonema spp. and Scytonema spp., Büdel et al. 2000) which are responsible for the frequent dark coloration of inselbergs. There is a floristic differentiation between individual microhabitats such as exposed rocky slopes, boulders and drainage channels. Lichens and cyanobacteria may form dense epilithic surface layers but they also occur endolithically to a considerable extent. Cryptogamic communities on inselbergs have very close relationships to those on other rock surfaces. Particularly well developed affinities exist to the Tintenstrich-communities that are ubiquitous on both anthropogenic and natural rocks in temperate and tropical regions. Floristically, cryptogamic crusts are relatively uniform and many taxa have wide distribution areas.

Epilithic vascular plants - This group comprises the nonmat-forming species that grow directly on open rock. Frequently these epilithic species are succulents or xerophytes. Prominent examples are provided by numerous orchids, e.g. in the neotropical genera Cyrtopodium and Laelia and the aroid genus Anthurium which possess water-storing pseudobulbs or leaves. Bromeliaceae too are very rich in epilithic species with Brazil being their center of diversity.

Monocotyledonous mats - Dense stands of monocotyledons occur on both flat and inclined open rocky slopes. These epilithic species are of mat-like appearance and are firmly attached to the rock by dense wiry roots. Frequently, monocotyledonous mats occur as isolated patches surrounded by open rock but large, continuous expanses of mats can also be found. Most typical mat-formers are Bromeliaceae, Cyperaceae and Velloziaceae. The latter two families contain long-lived, woody-stemmed species that are desiccation-tolerant. On South American inselbergs both tank-forming (e.g., Alcantarea spp., Vriesea spp.) and xerophytic (e.g., Dyckia spp., Encholirium spp., figure 2) Bromeliaceae occur from sea-level up to high altitudes as is the case in southeastern Brazil. In addition, the bromeliad genus Tillandsia (e.g. T. gardneri, T. tenuifolia) occurs with mat-forming species throughout many parts of this country. In tropical Africa and Madagascar desiccation-tolerant Cyperaceae and Velloziaceae are widespread on inselbergs. The Cyperaceae Afrotrilepis pilosa (figure 3) and Microdracoides squamosus occur as mat-formers in West Africa. In southern and eastern Africa and on Madagascar they are

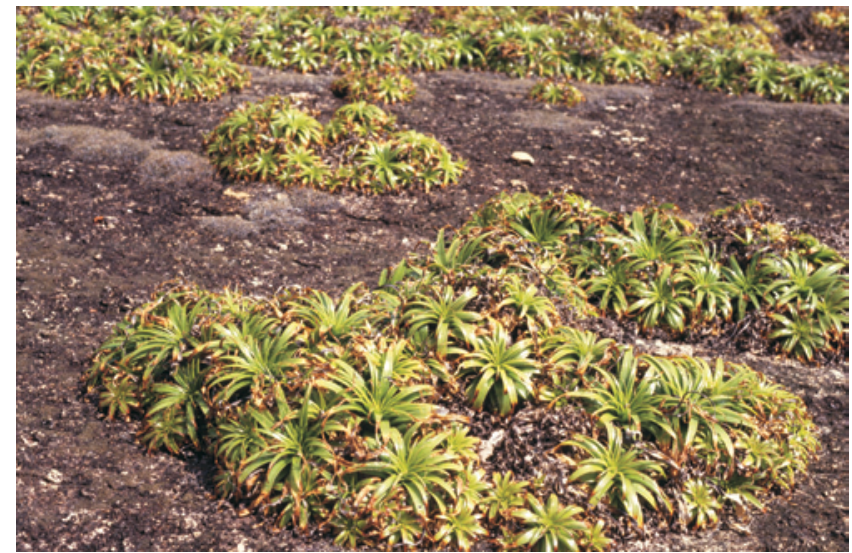

Figure 2. Mat formed by Encholirium spp. on inselberg in the Brazilian "Mata Atlântica" region (near Nanuque, Minas Gerais).

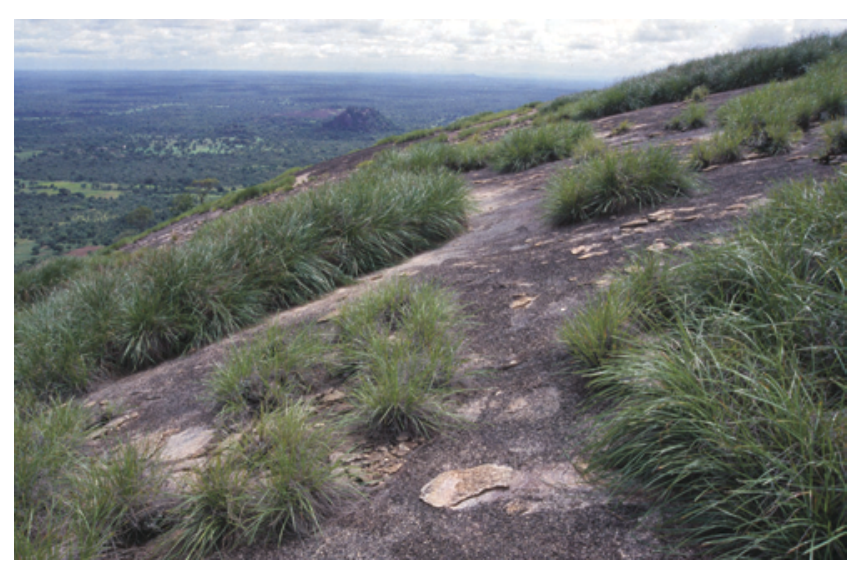

Figure 3. Afrotrilepis pilosa (Cyperaceae) is the dominant mat-forming species on inselbergs throughout West Africa.

replaced by the Cyperaceae genus Coleochloa (mainly C. setifera) and numerous species of the genus Xerophyta (Velloziaceae).

Remarkably, the woody fibrous stems of matforming Cyperaceae and Velloziaceae are occasionally colonized by phorophyte-specific epiphytic orchids. Amongst the orchids the genera Polystachya (tropical Africa), Constantia (Brazil) and Pseudolaelia (Brazil) comprise species that are restricted to monocotyledonous mats (Porembski 2005). Mat-forming ferns on inselbergs are confined to the genus Selaginella. Rock outcrop dwelling Selaginella species are desiccation-tolerant and are widely distributed in both tropical and temperate regions. In many cases Selaginella mats are monospecific communities.

Rock pools - Usually on level parts of inselbergs seasonally water-filled rock pools covering a wide range of sizes, forms and depths occur (figure 4). They are products of natural solution processes and may have a considerable 
age. Rock pools are mostly irregularly shaped depressions of variable depth, covering up to several square meters. They form a rather unreliable habitat for higher plants because they may dry out even in the rainy season during rainless periods. Typically epilithic and endolithic cyanobacteria and lichens form a dense cover on open rock walls. Cover by vascular plants is generally very sparse. Of widespread occurrence are plants that are otherwise frequent colonizers of marshy ground and ponds. The number of species restricted to rock pools is relatively low. Prominent examples occur within Scrophulariaceae (e.g., in the genera Dopatrium and Lindernia) and in the fern genus Isoetes (with highly specialized species in southeastern USA, tropical Africa, southwestern Australia).

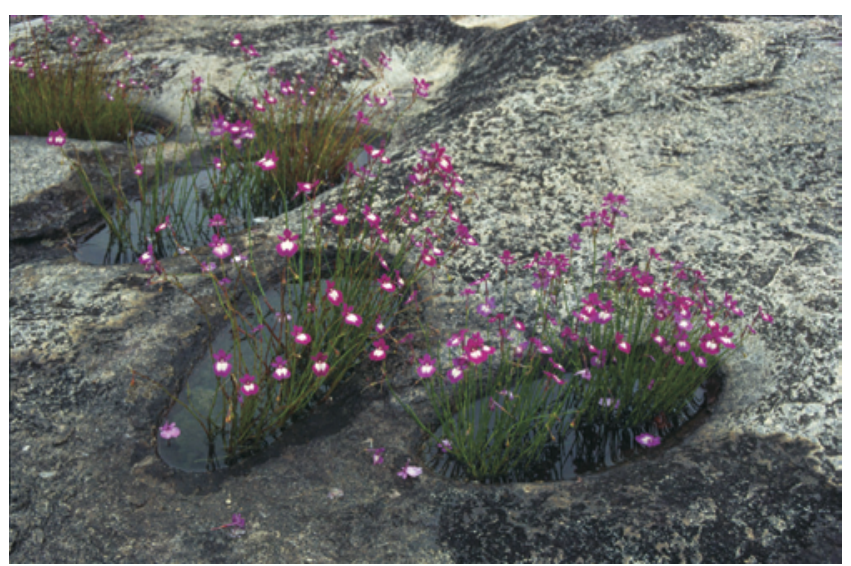

Figure 4. The Scrophulariaceae Dopatrium longidens is a typical colonizer of rock pools on West African inselbergs.

Shallow depressions - Small depressions filled with shallow substrate are widespread on inselbergs. In contrast to rock pools they are only briefly inundated (i.e. 1-2 days) following heavy rains. Substrate depth ranges between 2 and $20 \mathrm{~cm}$ and tends to increase from the periphery to the center. Usually vegetation cover is sparse with cyanobacteria, liverworts (frequently Riccia spp.) and mosses forming important elements. Moreover, annuals and to a lesser extent geophytes occur. Occasionally depressions containing deeper soils are colonized by trees and shrubs.

Crevices and clefts - Crevices that are less than $2 \mathrm{~cm}$ in width allow for only small amounts of soil to accumulate. Usually plant cover is very sparse with annuals preponderating. Under shaded conditions ferns and mosses may occur abundantly. Clefts are broader and deeper and offer establishment sites for perennial species. Under arid climates clefts form advantageous growth sites due to the good water storage capacity and the accumulation of considerable amounts of substrate.
Ephemeral flush vegetation - Located at the foot of rocky slopes or along the downslopes fringes of monocotyledonous mats this plant community depends on seepage water that is only available during the rainy season. The basic matrix is formed by Poaceae and Cyperaceae with numerous mostly diminutive annuals imbedded within. Typically the substrate is very shallow with the lowest values occurring towards the transition to the open rock. Nutrient availability is restricted which is reflected in the floristic composition of the ephemeral flush vegetation with Lentibulariaceae, Eriocaulaceae and Xyridaceae being usually well represented. Phytosociologically this plant community belongs to the class Drosero-Xyridetea that is particularly well developed on paleotropical inselbergs.

\section{Adaptive traits}

Inselbergs form centers of diversity for certain plant functional types that are well-adapted for survival under environmentally extreme conditions. In particular water scarcity and low nutrient availability have had a deep impact on the floristic composition of inselbergs. The microclimatical and edaphical dryness of inselbergs is reflected in the presence of numerous drought-adapted plants. Amongst them succulents and desiccation-tolerant vascular plants are particularly prominent. In the following a short survey on these xerophytic plant groups and their importance on inselbergs is given.

Succulents - On exposed rocky slopes of tropical inselbergs succulents occur as perennial lithophytes. In the paleotropics inselbergs in East Africa and Madagascar are particularly rich in succulents. Here Aloaceae (Aloe spp.), Apocynaceae (e.g. Pachypodium), Crassulaceae (e.g., Kalanchoe) and Euphorbiaceae (e.g., Euphorbia) comprise numerous inselberg endemics. On neotropical inselbergs Bromeliaceae (e.g., Encholirium), Cactaceae (e.g., Coleocephalocereus) and Orchidaceae (e.g., Cyrtopodium) occur with succulent species. Pachycaulous and caudiciformous species are widespread on tropical inselbergs. These plants possess fat water-storing trunks or a subterranean caudex. Comparatively rare are annual leaf succulents that occur on inselbergs in both tropical and temperate regions. Examples are Cyanotis lanata (tropical Africa), Sedum smallii (SE-USA) and the genera Crassula and Calandrinia which occur with several species on Australian inselbergs.

Most succulents are not absolutely restricted to inselbergs but occur in other dry localities as well. In many regions inselbergs form refugia for succulent plants which 
are highly sensitive to fire and thus cannot survive in many landscapes with a high probability of anthropogenic fire.

Desiccation-tolerant vascular plants - The vast majority of vascular plants cannot survive prolonged periods of desiccation. Only ca. 300 species of vascular plants can be classified as being absolutely desiccation-tolerant and are known as the so-called "resurrection plants" (Porembski $\&$ Barthlott 2000). Desiccation-tolerant vascular plants are extremely well adapted to withstand long periods of drought by resting in a state of dormancy. Details on the regulating factors of this sophisticated process were given by Black \& Pritchard (2002). Most resurrection plants lose their chlorophyll and other photosynthetic pigments, i.e. they are poikilochlorophyllous in contrast to relatively few desiccation-tolerant plants that keep their photosynthetic pigments during the process of desiccation and which are thus homoiochlorophyllous. Remarkably it has long been overlooked that tropical rock outcrops such as inselbergs form centers of diversity for desiccation-tolerant vascular plants. Monocots outnumber dicots among desiccation-tolerant vascular plants with Velloziaceae, Cyperaceae and Poaceae being particularly important. Prominent representatives within the Velloziaceae and Cyperaceae are arborescent matforming species that are typical elements on South American and African inselbergs. Desiccation-tolerant arborescent monocots are unique with regard to the possession of certain morphological and anatomical features. Their fibrous stems consist mainly of adventitious roots and old persistent leaf bases and may attain a height of several meters (overview in Porembski 2006). Surprisingly, the adventitious roots possess a velamen radicum that might be of functional importance for the rapid capillary uptake of rain water (Porembski \& Barthlott 1995).

On inselbergs desiccation-tolerant vascular plant species are mainly found as mat-formers but they also occur in shallow depressions and even in seasonally water-filled rock pools. A striking and highly specialised desiccationtolerant species in rock pools is the Scrophulariaceae Lindernia intrepidus (= Chamaegigas intrepidus), an endemic to Namibia. The behavior of this desiccationtolerant water plant has been described in detail by Heil (1925), Ziegler \& Vieweg (1970) and Hartung et al. (1998). The species has ephemeral swimming leaves on the water surface and perennial bulb-like underwater leaves. The swimming leaves die when the pools dry out whereas the underwater leaves and roots survive in a desiccated state for almost one year. Upon re-watering, the underwater leaves resume the physiological activity within a few hours. Subsequently new swimming leaves are quickly developed.

\section{Systematic overview}

There is a clear tendency for the flora of inselbergs to contain mainly rather advanced angiosperms. Pteridophyta, gymnosperms and basal angiosperms account for only a small percentage of inselberg plants (e.g., the fern genera Asplenium, Isoetes, Ophioglossum and Pellaea comprising a number of species restricted to inselbergs; within the gymnosperms only the cycads include a few species that are rock outcrop specialists). Within the angiosperms ca. 3500 species can be considered to be inselberg specialists (Barthlott \& Porembski 2000). Most speciose (i.e., each family contributing more than 300 spp.) are Poaceae, Cyperaceae and Fabaceae. These families contribute more than $30 \%$ of all inselbergs specialists. Other families particularly rich in inselberg specialists are Velloziaceae, Bromeliaceae, Commelinaceae, Lentibulariaceae, Eriocaulaceae and Xyridaceae. The latter three families comprise numerous annuals that grow in seasonally wet and nutrient poor localities. The most speciose genera on inselbergs are Vellozia, Rhynchospora, Utricularia and Cyperus all comprising more than 30 species that are habitat specialists.

With regard to the systematic composition of the inselberg flora there are strong region-specific differences. Only a few families (e.g., Poaceae, Cyperaceae) are of importance on inselbergs throughout the world. Most regions possess a characteristic set of families which are particularly prominent. Typical components on South American inselbergs are Bromeliaceae (e.g., Alcantarea, Encholirium, Pitcairnia), Cactaceae (e.g., Melocactus, Coleocephalocereus) and Gesneriaceae (Sinningia). On inselbergs in tropical Africa and Madagascar the Aloaceae (e.g., Aloe), Crassulaceae (e.g., Kalanchoe), Scrophulariaceae (e.g., Lindernia) and Myrothamnaceae contain typical inselbergs elements.

\section{Geographic patterns of plant species richness}

Floristically, inselbergs in different geographical regions are clearly distinct. Based on comparative floristic data collected over a broad geographical scale three hot spots of inselberg plant diversity can be identified which are both rich in species and endemics: a) southeastern Brazil, b) Madagascar and c) southwestern Australia. All three centers of inselberg plant diversity are located within biodiversity hot spots of global importance. 
It has to be emphasized, however, that for several tropical regions (e.g., Angola, India) our knowledge about the flora and vegetation of inselbergs is still sparse. Future research might thus reveal different views concerning the localisation of centers of diversity of inselberg vegetation. Southeastern Brazil - That the forest vegetation of the "Mata Atlântica" is rich in species and endemics is well known. However, it is frequently overseen that in this region (i.e., in particular parts of the Brazilian federal states of Rio de Janeiro, Minas Gerais and Bahia) rock outcrops not only form dominant landscape elements but also support large numbers of endemics. Remarkably high is the beta diversity (i.e., the degree of floristic differentiation over small distances) of the inselberg vegetation in southeastern Brazil with considerable species turnover between individual outcrops. The saxicolous vegetation of inselbergs in southeastern Brazil is extremely rich in dry resistant perennial species whereas annuals are relatively rare. Prominent examples are xerophytic and succulent bromeliads (e.g., Encholirium, Orthophytum, Pitcairnia, Vriesea, Tillandsia), cacti (e.g., Coleocephalocereus, Melocactus) and orchids (e.g., Cyrtopodium, Laelia). Moreover, resurrection plants occur abundantly and belong to genera such as Vellozia, Trilepis and to the fern genera Anemia, Doryopteris and Selaginella.

Madagascar - Madagascan inselbergs are particularly frequent on the Central Plateau where they are famous for their richness in succulent plants ("succulent paradise", Rauh 1995). Moreover, desiccation-tolerant vascular plants (e.g., Coleochloa, Myrothamnus, Selaginella, Xerophyta) occur profusely. The preliminary data available for this region show that the rock outcrop flora contains an extraordinarily high percentage of endemics. A considerable number of genera (e.g., Aloe, Cynanchum, Euphorbia, Kalanchoe, Pachypodium, Senecio) which obviously have radiated from Madagascan inselbergs. Madagascan inselbergs form a secondary center of diversity for the otherwise mainly neotropical genus Rhipsalis (Cactaceae) that mainly contains epiphytes. On Madagascan inselbergs neotenic forms of Rhipsalis (e.g., R. baccifera ssp. horrida) grow epilithically. Remarkably, many species on Madagascan inselbergs show a high degree of morphological differentiation over short distances making the limitation of taxa difficult (e.g., within Euphorbia and Xerophyta). Southwestern Australia - In this region inselbergs occur along steep climatic gradients from winter rainfall climate to inland desert. Species richness and endemism decline with increasing aridity (Hopper et al. 1997). Particularly striking is the richness in annuals with
Asteraceae, Stylidiaceae, Poaceae and Amaranthaceae being particularly speciose. Resurrection plants are mainly represented by the monocotyledonous genus Borya. Apart from a few tiny short-lived leaf succulents (Calandrinia spp., Crassula spp.) succulents are absent from inselbergs in southwestern Australia. Very rich in species are terrestrial Utricularia species which are typical components of seasonally wet vegetation types.

The reasons for the richness in species and endemics of inselbergs located in the above mentioned regions are not fully understood. All three regions are geologically old and stable and contain large numbers of available azonal sites. We can only speculate that the isolated position of rock outcrops together with their long persistence have contributed to the differentiation of local populations and thus have played a crucial role for speciation processes in these hot spot regions. In addition the three regions possess large species pools of suitable functional groups (both Brazil and Madagascar: succulents, Australia: annuals) what might also contribute to increased numbers of species on inselbergs.

\section{Comparison with other rock outcrops}

Apart from granitic/gneissic inselbergs numerous other types of rock outcrops occur as isolated azonal localities throughout the tropics. Prominent examples are the so-called "tepuis" that form characteristic landscape features in the Guyana-shield region in northern South America. Consisting of Precambrian sandstones "tepuis" bear high numbers of endemics and form ancient terrestrial habitat islands that are surrounded by either savanna or rainforest. In particular their summital parts are rich in endemics what might be due to long isolation from the surrounding lowlands (but see the discussion in Rull 2004). Based on data provided by Gröger (2000) it is known that in southern Venezuela a certain amount of floristic overlap exists between inselbergs and "tepuis". Flat-topped sandstone table mountains that show geomorphological similarities to the South American "tepuis" occur in the West African Fouta Djalon mountain range. Here too numerous endemics occur, among them the only paleotropic bromeliad Pitcairnia feliciana.

Important components of the surface geology and geomorphology of many tropical regions are duricrusts (e.g. ferricretes/ironstone outcrops) that may cover large surface areas (i.e. square kilometres). They frequently consist of a flat, infertile rocky pavement impeding the percolation of water. Inundated during rainy periods they are completely desiccated for most of the year and are naturally free of woody vegetation. In the rainy season 
ferricretes in tropical Africa and India are covered by large expanses of ephemeral flush vegetation with a high percentage of carnivorous plants (Porembski \& Watve 2005). Otherwise not much is known about this type of rock outcrop vegetation but there seem to exist floristic affinities to the vegetation of granitic/gneissic inselbergs. The importance of ironstone outcrops as centres of endemism and diversity has recently been emphasized by Jacobi et al. (2007).

Spectacular rock outcrops are the cone and tower karst hills in certain parts of the tropics (e.g., Malaysia, China, Cuba). According to Kruckeberg (2002) there is a paucity of floristic studies of these unique limestone landforms. Most detailed is the study of Borhidi (1991) who described the plant cover of Cuban cone and tower karst (locally known as "mogotes") which bear a flora rich in endemics.

\section{Conservational aspects}

Due to their environmental harshness inselbergs have not attracted much agricultural interest. In many regions inselbergs thus constitute relatively untouched ecosystems. However, the open character of their vegetation in combination with frequent climatic disturbances makes them susceptible to new colonists. Establishment opportunities for invasive weeds on inselbergs are provided by human impacts such as intentional burning, grazing and quarrying. In particular exotic annuals benefit from detrimental anthropogenic activities (Ornduff 1987, Ohlemüller 1997). A survey on the importance of exotic weeds as invaders of tropical inselbergs was given by Porembski (2000).

Apart from offering establishment opportunities for invasive weeds as a consequence of the above mentioned human practices there are other activities leading to the partial or complete destruction of the vegetation of inselbergs. In certain regions (e.g., India) inselbergs are worshipped for religious purposes, which has resulted in the construction of temples that over long periods have caused severe changes in the natural vegetation. Rather recent detrimental influences are related to leisure (rock climbing) and touristic activities (construction of buildings, cable cars). A particularly devasting form of human usage of inselbergs is large-scale quarrying due to an increasing demand for granite and gneiss for construction purposes. This can lead to their complete eradication at the landscape level as can be observed in certain regions of India (e.g., around Bangalore). Doubtless the loss of growth sites as a result of large-scale quarrying could cause the extinction of locally restricted species.
Acknowledgements - The author gratefully acknowledges financial support from the German Research Foundation (DFG). Many thanks to Wilhelm Barthlott (Bonn) for helpful discussions and to Fabio Rubio Scarano (Rio de Janeiro) for organizing the symposium about rock outcrop vegetation held at the 55 "Congresso Nacional de Botânica" in Viçosa (Minas Gerais, Brazil).

\section{References}

BARTHLOTT, W. \& POREMBSKI, S. 2000. Vascular plants on inselbergs: systematic overview. In Inselbergs biotic diversity of isolated rock outcrops in tropical and temperate regions (S. Porembski \& W. Barthlott, eds.). Ecological Studies. Springer-Verlag, Berlin, v.146, p.103-116.

BLACK, M. \& PRITCHARD, H.W. (eds.). 2002. Desiccation and survival in plants: drying without dying. CABI Publishing, Wallingford.

BORHIDI, A. 1991. Phytogeography and vegetation ecology of Cuba. Akadémiai Kiadó.

BREMER, H. \& SANDER, H. 2000. Inselbergs: Geomorphology and geoecology. In Inselbergs - biotic diversity of isolated rock outcrops in tropical and temperate regions (S. Porembski \& W. Barthlott, eds.). Ecological Studies. Springer-Verlag, Berlin, v.146, p. 7-35.

BÜDEL, B., BECKER, U., FOLLMANN, G. \& STERFLINGER, K. 2000. Algae, fungi, and lichens on inselbergs. In Inselbergs - biotic diversity of isolated rock outcrops in tropical and temperate regions (S. Porembski \& W. Barthlott, eds.). Ecological Studies. Springer-Verlag, Berlin, v.146, p.69-90.

DÖRRSTOCK, S., POREMBSKI, S. \& BARTHLOTT, W. 1996. Ephemeral flush vegetation on inselbergs in the Ivory Coast (West Africa). Candollea 51:407-419.

GRÖGER, A. 2000. Inselbergs: Flora and vegetation of inselbergs of Venezuelan Guayana. In Inselbergs biotic diversity of isolated rock outcrops in tropical and temperate regions (S. Porembski \& W. Barthlott, eds.). Ecological Studies. Springer-Verlag, Berlin, v.146, p. 291-314.

HARTUNG, W., SCHILLER, P. \& DIETZ, K.-J. 1998. Physiology of poikilohydric plants. Progress in Botany 59:299-327.

HEIL, H. 1925. Chamaegigas intrepidus Dr., eine neue Auferstehungspflanze. Beihefte zum Botanischen Centralblatt 41:41-50.

HOPPER, S.D., BROWN, A.P. \& MARCHANT, N.G. 1997. Plants of western Australian granite outcrops. Journal of the Royal Society of Western Australia 80:141-158.

JACOBI, C.M., CARMO, F.F., VINCENT, R.C. \& STEHMANN, J.R. 2007. Plant communities on ironstone outcrops: a diverse and endangered Brazilian ecosystem. Biodiversity and Conservation 16:2185-2200. 
KRUCKEBERG, A.R. 2002. Geology and plant life: the effects of landforms and rock types on plants. University of Washington Press, Seattle.

OHLEMÜLLER, R. 1997. Biodiversity patterns of plant communities in shallow depressions on Western Australian granite outcrops (inselbergs). M.Sc. thesis, University of Bonn, Bonn.

ORNDUFF, R. 1987. Islands on islands: plant life on the granite outcrops of Western Australia. Harold L Lyon Arboretum Lecture 15. University of Hawaii Press, Honolulu.

PHILLIPS, D.L. 1982. Life-forms of granite outcrop plants. American Midland Naturalist 107:206-208.

POREMBSKI, S. 2000. The invasibility of tropical granite outcrops ('inselbergs') by exotic weeds. Journal of the Royal Society of Western Australia 83:131-134.

POREMBSKI, S. 2005. Epiphytic orchids on arborescent Velloziaceae and Cyperaceae: Extremes of phorophyte specialisation. Nordic Journal of Botany 23:505513.

POREMBSKI, S. 2006. Vegetative architecture of desiccation-tolerant arborescent monocotyledons. Aliso 22:129-134.

POREMBSKI, S. \& BARTHLOTT, W. 1995. On the occurrence of a velamen radicum in Cyperaceae and Velloziaceae. Nordic Journal of Botany 15:625-630.

POREMBSKI, S. \& BARTHLOTT, W. 2000. Granitic and gneissic outcrops (inselbergs) as centers of diversity for desiccation-tolerant vascular plants. Plant Ecology 151: $19-28$.
POREMBSKI, S. \& BARTHLOTT, W. (eds.) 2000. Inselbergs - biotic diversity of isolated rock outcrops in tropical and temperate regions. Ecological Studies, Springer-Verlag, Berlin, v.146.

POREMBSKI, S. \& WATVE, A. 2005. Remarks on the species composition of ephemeral flush communities on paleotropical rock outcrops. Phytocoenologia 35:389-401.

POREMBSKI, S., BECKER, U. \& SEINE, R. 2000. Islands on islands: habitats on inselbergs. In Inselbergs - biotic diversity of isolated rock outcrops in tropical and temperate regions (S. Porembski \& W. Barthlott, eds.). Ecological Studies. Springer-Verlag, Berlin, v.146, p.49-67.

RAUH, W. 1995. Succulent and xerophytic plants of Madagascar. v.1. Strawberry Press, Mill Valley.

RULL, V. 2004. Is the 'Lost World' really lost? Palaeoecological insights into the origin of the peculiar flora of the Guayana Highlands. Naturwissenschaften 91:139-142.

SZARZYNSKI, J. 2000. Xeric islands: environmental conditions on inselbergs. In Inselbergs - biotic diversity of isolated rock outcrops in tropical and temperate regions (S. Porembski \& W. Barthlott, eds.). Ecological Studies. Springer-Verlag, Berlin, v.146, p.37-48.

THOMAS, M.F. 1994. Geomorphology of the tropics. Wiley, Chichester.

ZIEGLER, H. \& VIEWEG, G.H. 1970. Poikilohydre Pteridophyta (Farngewächse), Poikilohydre Spermatophyta (Samenpflanzen). In Die Hydratation und Hydratur des Protoplasmas der Pflanzen und ihre ökophysiologische Bedeutung (H. Walter \& K. Kreeb, eds.) Protoplasmatologia. Springer, Wien, v.2, p.88-108. 